"Até ao fim do mundo": Amor, rancor e guerra em Hélia Correia

"To the end of the world": Love, resentment and war in Hélia Correia

"Jusqu'à la fin du monde" : amour, rancœur et guerre chez Hélia Correia

Maria Manuel Lisboa

(2) OpenEdition

Journals

Edição electrónica

URL: http://journals.openedition.org/rccs/1081

DOI: $10.4000 /$ rccs. 1081

ISSN: 2182-7435

Editora

Centro de Estudos Sociais da Universidade de Coimbra

Edição impressa

Data de publição: 1 Junho 2004

Paginação: 65-83

ISSN: 0254-1106

Refêrencia eletrónica

Maria Manuel Lisboa, " "Até ao fim do mundo": Amor, rancor e guerra em Hélia Correia », Revista Crítica de Ciências Sociais [Online], 68 | 2004, colocado online no dia 01 outubro 2012, criado a 01 maio 2019. URL : http://journals.openedition.org/rccs/1081 ; DOI : 10.4000/rccs.1081 


\title{
"Até ao fim do mundo": Amor, rancor e guerra em Hélia Correia
}

\begin{abstract}
A peça de teatro de Hélia Correia, O rancor: Exercício sobre Helena, oferece a base para uma análise textual do entendimento clássico e moderno do papel da mulher no contexto da guerra. As mulheres, na versão contemporânea de Hélia Correia, reproduzem e acentuam alguns dos indícios já disseminados pela tragédia e epopeia gregas, nomeadamente a problemática da sexualidade feminina e da paixão, enquanto forças contrapostas ao instinto belicoso masculino, por aquelas eventualmente derruido. A leitura aqui apresentada focaliza aspectos variados da justaposição dos sexos no contexto da guerra: nomeadamente, a dinâmica entre mãe e filha enquanto agentes de um feminino solidário em confrontação com o imperativo belicoso masculino; a relação mãe-filho conforme inscrita no dilema edipiano filial de opção entre o pai guerreiro e a mãe atavicamente amada; a questão da maternidade/paternidade e do sacrifício voluntário ou recusado de filhos e filhas aos interesses da guerra; e o problema da representação passional do inimigo enquanto objecto de desejo e figuração do ideal do bem-amado.
\end{abstract}

Quando a morte cerrar meus olhos duros

- Duros de tantos vãos padecimentos,

Que pensarão teus peitos imaturos

Da minha dor de todos os momentos?

Vejo-te agora alheia, e tão distante:

Mais que distante - isenta. E bem prevejo,

Desde já prevejo o exato instante

Em que de outro será não teu desejo,

Que o não terás, porém teu abandono,

Tua nudez! Um dia hei-de ir embora

Adormecer no derradeiro sono.

Um dia chorarás... Que importa? Chora.

Então eu sentirei muito mais perto

De mim feliz, teu coração incerto.

Manuel BandeIRa (Soneto Inglês $n .^{\circ} 1$ )

An enemy is a friend waiting to be made.

Desmond Tutu (entrevista com Zahra Khalidi, Palestine-Israel Journal) 
O Acto Constitutivo da Organização das Nações Unidas para a Educação, Ciência e Cultura (UNESCO), redigido a 16 de Novembro de 1945, ainda à vista da carnificina da Segunda Guerra Mundial, abre com a declaração de que "como as guerras nascem no espírito dos homens, é no espírito dos homens que devem ser erguidas as defesas da paz", a fim de "preservar as gerações vindouras do flagelo da guerra [reafirmando] a fé nos direitos fundamentais do homem, na dignidade e no valor da pessoa humana" (UNESCO, 1945).

Deixando passar, por agora, e à excepção da última oração desta frase, a exclusiva referência a direitos do homem, algo que virá adiante a adquirir significado independentemente de um feminismo considerado por alguns como rezinguento e coca-bichinhos, a ênfase dada pela declaração acima citada ao papel fundamental da cultura em questões relativas à sobrevivência da espécie vem já de trás: "No princípio", diz-nos o Evangelho de S. João, "era o Verbo, e o Verbo estava com Deus" (S. João 1:1). No princípio, porém, diz-nos o Livro do Génesis, existia também, e existiu desde sempre, a guerra. Menos edificantemente ainda, e desde sempre - lembrando o mau exemplo de Jeová, castigador impiedoso dos filhos edénicos que tentaram infiltrar o que até aí era o monopólio paterno sobre a sabedoria, ou ainda o péssimo exemplo de Abel e Caim - a guerra em família e entre famílias.

Sigmund Freud, o grande superintendente da nossa sabedoria emocional contemporânea, debruçou-se, em torno da análise de fenómenos tais como o complexo de Édipo e o problema do tabu, sobre o ímpeto parricida de filhos contra pais, seleccionando, segundo esse critério de violência unidireccional, exemplos retirados da teologia e de clássicos antigos e recentes (Freud, 1962; Freud, 1991). Mas Freud, porventura, enganou-se e enganou-nos, ou, então, cedeu a um parti pris, ao dar uma prioridade paranóica ao instinto parricida. É possível demonstrar que o que manda na loja psíquica é o imperativo infanticida, de pais contra filhos, e não parricida, de filhos contra pais. Só quando o patrão está fora é que é dia santo na loja. Seja como for, o sangue derramado, com frequência inquietante, é o de um qualquer Eu em guerra contra os seus.

Quer no pelouro do mito, quer da religião, quer da cultura, quer, como exporei adiante, da psicanálise e, por associação, da família, a guerra bem entendida começa por casa. E que melhor exemplo de carnificina familiar do que o exemplo dos irmãos míticos Atreu (pai de Agamemnon) e Tiestes, este último levado à traição pelo irmão a aceitar o convite para um banquete em que "come os filhos guisados". Esta descrição de filhos guisados e de "uma família em que até já serviram [as crianças] ao jantar como prato 
principal”, é de Hélia Correia, em O rancor: Exercício sobre Helena (Correia, 2000: 13, 97), peça hilariante em que o panorama galopante da tragédia e da epopeia gregas transformadas em farsa nos alicia para o terreno de gargalhadas que, muito queirosianamente, nos deixam com mau travo na boca. A peça de Hélia Correia, pela sua dimensão dupla de ancestralidade e contemporaneidade, servir-me-á de ponto de apoio textual para o desenvolvimento de algumas considerações sobre o tema das mulheres e da guerra.

Os registos ancestrais do Mito e da Literatura estão semeados de banhos de sangue familiares, de despudores e de sem-vergonhas. Helena, esposa devassa e marafona, foge ao marido, causa mortandades sem fim ao longo de uma década, e ocasiona o ruir da civilização troiana, antes de regressar incólume ao marido e à pacatez da vida conjugal restaurada. Para além disso, e para refinar o insulto, quando lhe é imposto o embaraço de acolher Telémaco, filho de um Ulisses à data supostamente morto no regresso de Tróia - ou seja, indirectamente morto por culpa dela - a dita, na epopeia homérica, entrega-se a recordações assaz descontraídas acerca das suas aventuras na Ílion, e comenta que, efectivamente, poderia ter-se comportado melhor, "desavergonhada mulher que eu então era" (Homero, 1984: 68).

O perdão, e o auto-perdão, foram, para Helena, escandalosamente fáceis de alcançar, o que fará naturalmente engulhos a quem alimente pruridos mais rígidos em relação às fraquezas morais/conjugais femininas. Helena, está bem de ver, é a mãe-esposa despudorada que nos amamentou e aliciou no berço da nossa cultura. As páginas primevas dos Gregos estão povoadas das suas irmãs (incluindo irmãs de facto, não metafóricas): Clitemnestra, assassina de um marido infanticida da própria filha; Medeia, assassina dos filhos do marido infiel; Antígona, parente insubordinada e semeadora de discórdia. Etcetera. Duas componentes constituem os factores constantes e as circunstâncias atenuantes destas várias equações de insurreição feminina: primeiro, tratar-se de crimes em resposta a uma provocação e, segundo, a realidade de mulheres apanhadas em conflitos familiares, políticos e nacionais regidos por imperativos masculinos belicosos que a elas só tangencialmente, embora com a maior pungência, diziam respeito.

Primeiro, então, a provocação. Axioma: um pai que mata uma filha por motivos de avanço na profissão merece a morte às mãos de qualquer mãe digna desse nome; quanto mais um pai que, tal como Agamemnon, matou, não uma, mas duas filhas daquela mater dolorosa, brutalmente traduzida em criminosa descontrolada, que foi Clitemnestra. É sabido que Agamemnon sacrificou Ifigénia aos deuses em troca de uma brisa propícia à largada para Tróia (Eurípides, 1978). O que é menos sabido é que o mesmo Agamemnon matara também já outro filho (ou filha, conforme a 
versão), que Clitemnestra trouxera de um casamento prévio (Grant e Hazel, 1993: 16). Perante esta provocação dupla, que mãe não teria feito o mesmo? Em $O$ rancor, Etra, rainha transformada em escrava, figura angustiosa mas nunca angustiada e sempre espirituosa, comenta em jeito de conversa ligeira que "os vencidos desenvolvem uma estranha aptidão para a mentira, sofrendo, por conseguinte, de uma espantosa falta de rigor" (38). Não sem justificação, diríamos nós agora, visto que a História, como é sabido, nunca foi escrita nem pelos vencidos nem para os vencidos. Seja pela via da mentira, da intriga, da traição ou do homícidio, há vinganças que são não só justas e compreensíveis, como necessárias. Ou não seja verdade que em tempo de guerra tudo vale, até tirar olhos, incluindo, está bem de ver, as guerras começadas por outros, e combatidas segundo as regras dos outros.

Passando, em segundo lugar, à questão do feminino encurralado em conflitos alheios, em $O$ rancor, Helena observa que quando "as mulheres falam contra a guerra, os homens zangam-se" (14), e ainda que "tem muita fome, a guerra. E boa boca. Não escolhe a qualidade da comida. Se novos não houver, os velhos servem" (27). A percepção feminina da guerra, que para as mulheres, efectivamente, de um modo geral é a guerra dos outros, ou de um Outro masculino, contrasta acentuadamente com a visão masculina, conforme transmitida aqui por Menelau, que, embora confessando que "esta guerra contra Tróia [tenha sido excessiva]. Longínqua, prolongada, invernos, verões, falta de banhos. E de fruta, já se vê" (23-24), dela conserva boas recordações:

Lá uma guerrazita de vez em quando, um saque, umas escravas, não está mal. É como os jogos: exercita os músculos e até se não se ganha alguma coisa valeu a pena ter participado, mais que não seja pela mudança de ares. (23)

Ganhar ou perder é desporto, seja na guerra ou não seja, e a guerra, como fica estabelecido, pode ser um bom desporto. Para Menelau, a guerra é "uma grande senhora", ao passo que, para Etra, representante do sofrimento feminino grego (rainha de Atenas) e troiano (porque capturada como espólio de guerra em Tróia), a guerra é "uma cabra" (15). Resume-se aqui o fenómeno, histórica e antropologicamente aceite, mas, como argumentarei adiante, também contestado e em Hélia Correia desconstruído, segundo o qual o homem está para a guerra como a mulher está para a paz, em oposição hegeliana (heliana?) sem síntese visível. O binómio guerra/paz, então, intuitiva e culturalmente, segundo a sabedoria vigente, põe a mulher em paralelo com a paz, situando o homem nas fileiras da guerra, sendo que à mulher 
compete parir e ao homem matar. A pergunta chistosa feita em França a uma mãe de muitos filhos, "vous travaillez pour l'armée, Madame?", é a articulação jocosa, mas pungente, do imperativo que à mulher exige que perpetue ad infinitum o abastecimento de carne de canhão, parindo para fornecer os filhos da geração guerreira seguinte, a qual ao homem, por sua vez, de seu direito, e se assim the convier, cumpre ciclicamente chacinar.

Será então um facto incontestável que o pelouro da produtividade e da procriação é feminino e o seu oposto masculino? Ideia algo contraditória no contexto de uma tradição metafísica greco-judaico-cristã dominada por versões múltiplas, divergentes e contraditórias dos processos de origem e perpetuidade: por um lado, o guião prototípico de mulheres semeadoras da discórdia entre machos (Eva, Helena, Ginebra, Iracema, etc.); por outro, o de um Deus-Pai criador supremo e governante de mulheres submissamente subalternas, preponderantemente passivas e apenas secundariamente participantes (enquanto escravas do Senhor) no processo de geração; e, por fim, o de um Deus potencialmente cataclísmico e aniquilador dos seus insatisfatórios filhos (é ver os exemplos de Adão e Eva, do dilúvio genesíaco, ou das cidades da planície).

Seja como for, à mulher, como já ficou dito, compete parir, com certas excepções - tais como, por exemplo, a Medeia de Eurípides, que, como é sabido, afirmou que, perante a dor do parto, preferiria combater três vezes na frente de batalha do que parir um único filho (Eurípides, 1986: 25). Pode argumentar-se que quem enfrenta a dor inerente ao acto de dar à luz tem uma aversão maior a matar o que tanto trabalho (de parto) lhe deu a produzir. Não matarás. Afigura-se-nos que o sexto mandamento da lei de Deus, embora assuma autoria e enunciação masculina, é de sua essencial natureza feminino, conforme atestam aliás as estatísticas universais do crime de homicídio, quase invariavelmente um acto de origem masculina, em qualquer país e em qualquer época. Quando produz um filho ou uma filha, a mulher investe em ver a sua obra perpetuada. Quando produz um filho, o homem investe em ver-se a si próprio perpetuado. E quando produz uma filha, que não lhe transmitirá o nome, não investe nada. É a diferença entre a arquitectura construtiva de moralidade a longo prazo e o narcisismo potencialmente sem saída a curto ou médio prazo.

Com referência a Homero, Eurípides, Virgílio, Chaucer e Shakespeare, Lorraine Helms desenvolve o conceito da guerra à outrance combatida pelas mulheres nas tragédias destes autores, ou seja, a guerra combatida em paralelo à luta armada convencional, e que visa o desiderato não de destruição do oponente, mas antes de defesa e protecção dos seus ou, no mínimo, de reconstrução resgatada das ruínas, como alternativa à acção guerreira mas- 
culina (Helms, 1989: 25-42). Nesta guerra à outrance, o amor desempenha um papel que Barbara Freeman, em outro ensaio, com razão rejeita enquanto antítese da guerra, entendendo-o antes como participante - com voz diferente - no mesmo diálogo mortífero (Freeman, 1989: 303-322). No entanto, ele pode funcionar não só como agente subversivo, mas ainda como arauto da sua longevidade triunfantemente superior. Haverá tema mais português do que o de uma Inês de Castro cujo ímpeto amoroso sobrevive inscrito nos túmulos de Alcobaça, "até ao fim do mundo", enquanto os imperativos políticos que a condenaram estão há muito esquecidos? Em Hélia Correia, perante o ímpeto belicoso masculino de Gregos e Troianos, perante a misoginia de Aquiles e Pirro, perante o paternalismo alvar, embora mais ou menos bem intencionado, de Menelau e perante a perplexidade confusa de Telémaco e Orestes perante os efeitos do imponderável feminino, a táctica de guerrilha desenvolvida por Helena, Etra e Hermíone confronta a simplicidade de sangue masculino e masculinamente (masculamente) derramado com a complexidade de hipóteses alternativas: nomeadamente, a recuperação histórica da voz dos vencidos (e vencidas), a formulação de categorias humanas opcionais (femininas), a revisão de conceitos estabelecidos (de valor e de heroísmo, de culpa e de castigo), e a reversibilidade do problema da ausência, morte e obliteração do Inimigo/Outro bem-amado.

\section{Olhar para Ontem}

Em $O$ rancor, este reaver do desejado perdido, conforme acima identificado, adopta uma série de formatos divergentes. Pirro, digno filho do embirrento Aquiles, reclama o dia em que - estando Menelau e Helena já residentes nos infernos - passará a ser rei de Esparta, e recebe como resposta por parte de Hermíone, sua esposa e filha daqueles, o remoque de que nem ele nem nenhum seu sucessor jamais passará de "marido da rainha, faz favor." Pirro responde que "isso acabou" (31-32), e Etra confirma que "o poder das mulheres já não existe" (32), e Menelau resume com complacência que “o que lá vai, lá vai. Já é passado" (30). Em vez desse passado que as mulheres recordam com nostalgia mas que os homens se apressam a esquecer, deparamos, porém, em $O$ rancor, com um presente povoado de homens cujo ostensivo exercício de poder sexual, belicoso, doméstico e político, deixa entrever nos bastidores as fracturas que assinalam a masculinidade precária por detrás da violência exibicionista. Temos assim o exemplo de Menelau, cujas fantasias acerca de uma Helena já reavida apenas subsistem à custa da ilusão que a reinventa enquanto escrava estrangeira e cativa, Outra, trazida como troféu de guerra. 
MENELAU - Já passara tanto tempo... Tinham-te recebido na família. Falavas e vestias como elas. Pode dizer-se, sim, que eras uma princesa troiana como as outras, e que eu te ganhei como presa de guerra.

HELENA - É isso que imaginas, não é, marido meu, sempre que me desejas no teu leito? Que tens uma mulher vencida as tuas ordens? (42)

Ou ainda o exemplo de Aquiles, violador da rainha amazona Pentesileia já morta, e apenas quando morta, desejável (100). Ou o de Pirro, impotente com a mulher porque "uma mulher que livremente o aceitou não o interessa" (99), e apenas sexualmente capaz com mulheres concreta ou metaforicamente mortas (as escravas pontualmente encontradas degoladas em recantos escuros do palácio; Andrómaca, testemunha petrificada - morta-viva - do infanticídio do filho bebé, atirado por Pirro das muralhas de Tróia):

HELENA (para Pirro) - Amas a morte e as mortas, não as vivas. Por isso Andrómaca concebeu dois filhos teus. Porque a pobre cativa morreu naquele momento em que tu lhe arrancaste o filho do regaço. Estava branca e gelada, e assim ficou. (101)

A proclamação de Pirro, de que "nada do que se faz num campo de batalha é criminoso [...]. O guerreiro confere grandeza a tudo. Até mesmo o seu mijo tem grandeza" (95), carece, por isso, de poder persuasivo perante actos que a desmentem, e que ficam afinal claramente classificados como crimes (de guerra), que, como se sabe, na ética clássica de crime e castigo, mais tarde ou mais cedo se pagam.

\section{O que parece não é}

No segundo acto, Helena, antes de se inteirar de que o visitante semi-enlouquecido, recém-chegado a Esparta, é Orestes, filho matricida de Clitemnestra, e seu sobrinho, recomenda a Etra que, como louco que é, o trate bem, porque os loucos "são seres sagrados, embora normalmente cheirem bastante mal" (55). A conjuntura de reverência tradicionalista e irreverência corriqueira coaduna-se com a forma como, em O rancor, de um modo geral, as expectativas relativas às personalidades, naturezas e acções dos protagonistas em questão, conforme evocadas pelo tema e género literário (epopeia homérica, tragédia clássica), são quer cumpridas, quer desmontadas pela via da farsa. A cólera grandiosa de Aquiles no texto original homérico é aqui apresentada à distância como uma mistura de birra infantil e psicopatologia monstruosa. O estatuto de Etra, antiga rainha de Atenas, voluntariamente auto-oferecida como refém de Helena e Menelau, resulta 
numa escrava que trai a patroa sempre que ocasião para tal se apresenta. Porém, ri-se com ela à laia de cúmplice ante o desconcerto de Menelau frente aos embustes da mulher, e, com genuína ternura, confessa a Helena não ser capaz de adormecer de noite antes de lhe ter aconchegado a colcha, como qualquer mãe extremosa. E, mais dramaticamente, a própria Helena descobre tardiamente ter sido não afinal a tia, mas sim a mãe, agora enlutada, da sacrificada Ifigénia, postumamente desvendada como sendo não sua sobrinha, mas a filha que lhe fora roubada à nascença e falsamente proclamada nada-morta. Por conseguinte, o que parece, nem sempre, ou quase nunca é. E esta incerteza perene aplica-se até, ou sobretudo, àqueles conceitos que acima de todos os outros regem a lógica, a moralidade e a ética da Grécia antiga, nomeadamente os problemas da fatalidade, da responsabilidade e da culpa.

No final do primeiro acto, Telémaco lastima que, tendo quase terminado a sua visita a Esparta, embarque sem ter visto os famosos cabelos de Helena "tanto deles falam todos os poetas" (43), cabelos esses agora sempre ocultos sob a cabeleira egípcia que Helena nunca abandonara desde que regressara de Tróia. Depois de algum debate, Menelau arranca-lhe a cabeleira, e a assembleia estarrecida verifica que a bela Helena traz a cabeça rapada, sinal conhecido de luto arvorado pelas viúvas inconsoláveis, mas também, contrariamente, pelas esposas apanhadas em flagrante delito ("HELENA - Como as viúvas! Como as descasadas!” [52]). Após a revelação de luto perpétuo por um Páris supostamente esquecido, porém, verifica-se agora, afinal sempre lembrado, Etra comenta que, contra todas as aparências de uma dor desatinada, Helena nunca enlouquecerá, porque "somente os inocentes enlouquecem” (48). Mas, em Hélia Correia, a questão da culpa e do seu castigo fica sempre fluida e indefinida, seja ela a culpa de Clitemnestra ao matar o marido ("qualquer mãe mataria o assassino de sua filha," 62; "Qualquer deusa-mulher lhe perdoava," 79), ou seja a da própria Helena, suposta causadora da guerra de Tróia, mas porventura absolvida, perante outros motivos mais prováveis:

HELENA - Ai, houve tanta gente a querer-me mal... Como se a guerra fosse culpa minha. Quando não passou tudo de um jogo de imortais.

HERMÍONE - Dizem até que Zeus quis esta guerra para livrar a Terra de bom número de humanos. Que havia gente a mais e era preciso uma matançazinha. (28)

ORESTES - O que tinham os gregos a ver com a cidade de Tróia, não me dizes? [...] Se não fosse o rapazinho mimado por seu pai a vir buscar a prenda que lhe dera Afrodite... 
ETRA - Pois aí tens. Seja qual for o modo de se encarar a coisa, Helena acaba sempre por ficar inocente. A deusa prometeu-a a Páris, que a ganhou, como se ganha um belo cavalo nas corridas. (56)

ETRA - A que remorsos julgas ter direito? Destruiste meio mundo, é certo, mas que culpa terás tu da promessa de Afrodite? (76)

Curiosamente, as Fúrias ou Erínias, deusas do remorso que aplicadamente perseguem Orestes enquanto filho matricida, são primeiro invisíveis perante Helena ("ORESTES - Tendes assim as almas tão limpas de pecado?" [53]), depois inofensivas ("As Erinias, a um canto, desafiam Helena com os seus sons, mas mantêm distância, como se a receassem" [75]) e, por fim, transformam-se em suas escravas ("ORESTES - Há que pedir a Apolo que as faça retirar. HELENA - Quem? As minhas escravas? [...] As Erinias resistem um pouco, mas parecem entontecidas e aceitam o seu papel. Dançam e servem à mesa" [109]). Será Helena, por conseguinte, verdadeiramente culpada, quando nem as próprias deusas do remorso a vislumbram como alvo merecedor de perseguição ? Quem tem culpa de quê? Quem define a culpa? Quem institui o castigo? Quem é castigado?

\section{Meninas da sua mãe}

Tradicionalmente, as mulheres participam nas aventuras guerreiras dos machos proporcionando-lhes adulação ("todas as mulheres gostam de um homem de uniforme"), abastecimento de combatentes (filhos) e um lar ao qual regressar. Porém Cooper, Munich e Squier questionam a força dos estereótipos do homem guerreiro e da mulher que no lar o espera e chora, e elaboram o conceito do "momento contraceptivo" em textos em que se verifica que a protagonista feminina se desliga das suas funções tradicionais de carpideira e fornecedora de futuros soldados (Cooper et al., 1989: 9-24). Esse momento de recusa simboliza também a rejeição de uma função de cumplicidade com o empreendimento de guerra. Em O rancor, a possibilidade de continuidade do macho, quer como indivíduo (homem, marido, pai), quer como participante da máquina bélica (guerreiro, líder, rei) - e, a partir daí, a longevidade do projecto de guerra que ele valoriza e perpetua ("a guerra é uma grande senhora") - aparece explícita e duplamente ameaçada: primeiro, pela impotência de heróis jactanciosos, mas sexualmente inviáveis (Pirro), incapazes de cumprirem o seu papel fecundador na produção da geração seguinte de filhos e soldados ("TELÉMACO - E se nem houver filhos? Acontece. HERMÍONE - Acontece. Está sempre a acontecer." [26]). E, em segundo lugar, pela agressividade nem sequer 
dissimulada de mulheres (esposas) que, em vez de chorarem guerreiros mortos, potencialmente encorajam essas mortes ou nelas participam. Em O rancor, os dois fenómenos coincidem na pessoa de Deífobo, segundo marido troiano de Helena após a morte de Páris, o qual, na versão pressurosamente oficializada por Menelau, foi morto por aquela sem dela usufruir conjugalmente:

MENELAU - Casaram, isto é... Que não se leve à letra. Uma formalidade. Não se esqueçam de que Tróia era já Ásia. Tinha costumes muito... estranhos, para nós. De qualquer modo, Helena estraçalhou-o. Sim, senhor. Estraçalhou-o sem piedade. Ao que se diz, a ponto de a sua própria mãe não o reconhecer. Foi ou não, querida? HELENA - Eu tinha de fazer qualquer coisa...

HERMÍONE - Estraçalhar maridos é um bom passatempo. (23)

Para além da neutralização ou não-consumação sexual (Pirro, Deífobo) e do homicídio (Deífobo, Agamemnon) restam ainda duas estratégias por via das quais o desígnio guerreiro é inutilizado pela instância feminina: primeiro, através da produção, não de filhos mas de filhas, e segundo, por meio da metamorfose do guerreiro em menino da sua mãe.

No primeiro caso, e fazendo eco de Naomi Segal, "há duas cadeias genealógicas no contexto das quais a mãe pode integrar-se":

[A mãe] ou se inscreve numa estrutura patrilinear, dando um filho ao seu pai ou marido, ou se situa numa estrutura matrilinear, dando uma filha à sua mãe. [...] As mulheres que são mães na literatura de autoria masculina são pouco numerosas, habitualmente engravidando - com frequência como resultado de uma noite de núpcias super-potente - com o objectivo de exemplificar o trauma obstétrico. As mulheres que dão à luz filhas são ainda menos numerosas e um número extraordinário são adúlteras. [...]

Há algo nas mulheres discernidas como seres sexuais que, ao que parece, faz com que mereçam o castigo de se reproduzirem a si próprias; o adultério desqualificou-as da única tarefa aprazível que Freud identificou como dar à luz um rapaz. (Segal, 1990, 136-137)

Segal, porém, identifica outra possibilidade, nomeadamente a de uma dinâmica entre mãe e filha, sendo que, para além do padrão de narcisismo e auto-repetição que, segundo a óptica masculina, circunscreve o acto de uma mulher que dá à luz uma filha, deparamos com um potencial "outro-mundo" - subreptício e porventura ameaçador - em que as mulheres dialogam e se amam entre si: "Nas mães de filhas [o homem] vislumbra 
uma maneira oculta por meio da qual a mulher ama a criança mais exactamente carne da sua carne, na qual o marido não deixou rasto" (Segal, 1990, 137-38). Não deixou rasto ou, se deixou, teme vê-lo variamente apagado por mulheres que fazem eclipsar o marido/pai sem sequer terem o pudor de com ele se parecerem: "HERMÍONE - Estraçalhar maridos é um bom passatempo. PIRRO - Minha mulher Hermíone tem carácter. Sai à mãe." (23, sublinhado meu).

Em segundo lugar, se a mulher-mãe ameaça desconstruir o edifício de glória guerreira do macho fornecendo-lhe não um filho que o imite, mas uma filha que dele dissida, quando é produzido um filho, o potencial impacto da mãe sobre esse descendente, que teoricamente providenciaria ao macho a garantia de continuidade, torna-se porventura ainda mais controverso.

No segundo acto, Orestes, previamente compelido ao matricídio para vingar o pai que Clitemnestra assassinara, aparece em Esparta, perseguido pelas Fúrias, e depara com Helena, despojada da sua cabeleira egípcia, careca e com aspecto de mendiga. O fascínio que Helena, seja qual for o estado em que se encontre, exerce indiscriminadamente sobre os que a rodeiam, já anteriormente bem documentado ("ETRA - Sabes qual foi maior humilhação do que ser tua escrava? Foi amar-te.” [78]), culmina, no caso de Orestes, no efeito habitual de um homem absolutamente rendido, quer no sentido sexual, quer militar da palavra. Já antes do encontro entre Orestes e Helena se tinha verificado a vigência de uma confusão entre sexualidade e maternidade, e o poder que essa confusão, justamente por sê-lo (mãe/amante), exerce sobre a prepotência masculina supostamente triunfante:

TELÉMACO - Contam que Menelau, em cólera, seguiu a bela Helena ao longo das muralhas de Tróia, decidido a matá-la, por vingança. E que ela, de repente, se deteve e virou-se de frente para ele. E que um seio se avistava, porque a veste tinha sido rasgada e descaíra. E Menelau ajoelhou e perdoou-lhe, novamente perdido de paixão. (102)

Se Menelau ficara rendido (perdido) ao vislumbrar o peito de Helena, foi este porventura o resultado não só de desejo sexual mas também filial - visto que é com o seio que a mãe amamenta o filho. É também esse desejo bifacetado que o atrai de novo a uma domesticidade restabelecida com a esposa marafona, mas também condescendentemente maternal ("HELENA acaricia[-o] com desprezo" [42]). E também Orestes, no momento da grande confrontação com a mulher que causara a guerra da qual resultaram todas as outras mortes familiares (a carnificina nos campos de Tróia, o sacrifício de Ifigénia, a retaliação de Clitemnestra contra Agamemnon e o assassínio 
daquela como vingança filial), também ele fica rapidamente reduzido à condição de menino na mão das bruxas, ansioso por refúgio no colo carinhoso de uma mãe. De uma qualquer mãe, até mesmo daquela Helena a quem ele, à laia aliás de típico filho sofocliano e freudiano, tão frequentemente apelidara de "a maior das putas" (55):

Orestes dormitando no regaço de Helena. [...] HELENA - Já me basta ter este aqui, adormecido nos meus braços, inteiramente à minha mercê, e no entanto as minhas mãos não querem fazer mais do que acariciá-lo e protegê-lo. [...] Que vou fazer com ele? Por que razão o trouxeram as fúrias para cá? Coitadinho é ainda uma criança. (78)

Psiquicamente, a cronologia freudiana estabelece que o filho ama a mãe e odeia o pai, mas subsequentemente abandona a mãe e passa a identificar-se com o progenitor congénere. Todavia, em $O$ rancor, a associação entre Clitemnestra e Helena, culpadas de análogos crimes de traição contra maridos e patriarcas, inverte a transição da mãe para o pai no trajecto amoroso de Orestes, o qual desiste de assassinar a tia como assassinara a mãe. Em vez disso, através do encontro com a tia, Orestes revive o momento da morte da mãe às suas próprias mãos, mas, acima e para além deste acontecimento sangrento, relembra nostalgicamente o momento do seu próprio parto (sendo qualquer parto, por natureza, um acontecimento também sangrento), e ainda o amor que edipianamente sempre sentira pela mãe. Amor nunca tão angustioso como na ocasião em que, ao matá-la, presenciara também a cena primeva freudiana de Clitemnestra nos braços do pai (ou padrasto) rival:

ORESTES - E se, chamado pela irmã, o rapazinho regressasse a Micenas para vingar a morte e a desonra do pai?... Se entrasse no palácio, devagar, pé ante pé, a percorrer os corredores de que não tinha o menor eco na memória, guiado apenas pelo gemido dos amantes, ocultos nas cortinas doiradas do seu leito... E tudo o que ele queria era encostar-se ao regaço da mãe, de quem tivera tanta, tanta saudade ao longo de todos aqueles anos no exílio... E quando o braço com o punhal desceu sobre os dois corpos que dormiam enlaçados, e o sangue o atingiu em pleno rosto, ele viu os olhos dela e desejou que tudo se tivesse passado exactamente de maneira contrária. Ele de bom grado mataria a irmã, e o pai, e a tia, Helena, a grande prostituta. (69, sublinhado meu)

Não existia mais ninguém no mundo, além de um filho e sua mãe que ali morria às suas mãos, tão devagar... E agarrava-se a ele, ó deuses, escorregando na maciez do sangue... E olhava, olhava, e não tinha surpresa no olhar, só uma espécie de doçura, a dor de um parto novamente vivida, que ela, sim, reconheceu Orestes... (70, sublinhado meu) 
E o filho, a querer sustê-la, escorregava também. Um longo abraço. Nunca um filho amou tanto a sua mãe como Orestes naquele momento em que a matou. O que ele daria para voltar atrás. Para ficar ao lado da mãe puta, assassina do pai, madrasta de seus filhos... (71, sublinhado meu)

O que ele daria para voltar atrás, ou seja, para regressar psiquicamente ao útero, ao estado pré-edipiano e amniótico de fusão com o corpo materno. Se o assassínio da mãe é outra versão, apenas um pouco mais brutal, da traição edipiana da progenitora freudiana pelo filho, em $O$ rancor, afinal de contas, é a mãe, ou a sua suplente, Helena, quem triunfa e permanece, enquanto rainha, amante, amada e mãe: "Olhai: Helena afaga o seu sobrinho e ele depõe armas e aceita o seu afago" (Correia, 2000: 83). "Vamos ter outra cena de incesto na família" (Correia, 2000: 78). Haverá, para o homem, pesadelo mais imponderavelmente paradisíaco e mais visceralmente temível do que esse, do regresso ao ventre materno restaurado, e à mãe uterinamente amada?

A existência física e mental do recém-nascido depende [exclusivamente] da mãe [...] e leva-o a uma sensação de união tal que a consciência do eu requer também a consciência da possibilidade de separação da mãe. A mãe é o ser que o filho ama com amor auto-centrado e primário, e à qual fica fundamentalmente ligado. [...] Em fases posteriores, a relação inicial com a mãe leva à preocupação com questões de intimidade e de fusão. [...] Quem viveu esse amor primário, deseja sempre recriar a sensação de fusão [...] mas o medo de fusão pode vir a exceder esse desejo. (Chodorow, 1979, 78-79).

Os homens ainda não articularam a violência do impulso que os atrai para a mulher, e, em paralelo a esse desejo, o pânico de que, através dela, possam morrer e desvanecer-se. (Horney, 1993, 134).

\section{Amor com amor se paga}

ETRA - Que direito [tenho eu]? Uma escrava!

TELÉMACO (rindo) - Uma escrava!... Mulher do rei Egeu, mãe de Teseu, o salvador de Atenas, uma escrava... Ah! Ah! (Olhando em volta os rostos sérios) Uma escrava? MENELAU - Uma escrava... São modos de falar. Escrava, rainha, que diferença faz? (31)

A perpétua incompreensão de Telémaco, a quem tudo tem que ser constantemente explicado, e o modo descontraído como Menelau põe de parte como desnecessárias e picuinhas as definições e rótulos que identificam o 
status quo que governa (distinções entre rainha e escrava, esposa casta e esposa foragida, mulher honrada e prostituta), explicam não só as origens iniciáticas do problema (a fuga de Helena com Páris), mas também a sua conclusão.

O nosso entendimento dessa conclusão depende da nossa capacidade, enquanto leitores, de digerirmos dois factos: primeiro, o facto de que, citando Cooper et al., "pode ser que num mundo patriarcal os homens assinem os contratos de guerra, mas as mulheres contribuíram para redigi-los" (Cooper et al., 1989: 10). E, segundo, conforme argumentado por Adam Phillips, o facto de que se, pós-Freud, o inconsciente nos surge como mais legível, essa legibilidade aumentada relaciona-se com um entendimento da guerra, ou, especificamente, da colaboração entre guerra e amor, Eros e Tânato (Phillips, 2000a: 42). Psicanaliticamente, a necessidade edipiana - e, portanto, primordialmente masculina - de um inimigo contra o qual erigir o eu psíquico, fundamenta o desenvolvimento psicológico do indivíduo. Nas suas "Reflexões tempestivas sobre a guerra e a morte" (1915), Freud sugeriu que todos dependemos de um inimigo, seja ele um inimigo externo ou um inimigo dentro de nós, contra o qual possamos reagir. "Haverá algo mais inspirador do que um inimigo? [...] Sem esta magnitude do que é mau, seria possível esta intensa consciência do que é bom?” (Phillips, 2000a: 45). A representação do Mal inspira o Bem. Durante períodos de guerra, o inimigo externo providencia uma série de representações "prontas-a-vestir" dos nossos medos. O inimigo externo, menos perigoso porque externo, associa-se ainda ao inimigo interno do eu impelido para o instinto de morte (Tânato) que Freud também investigou (Freud, 1961). A guerra evoca recordações de medos atávicos da infância primeva, mas oferece também a possibilidade de evasão a esse inimigo residente portas-a-dentro, o inimigo do/no eu, porque encarna o inimigo em formato exterior a esse eu, e apresenta-o sob uma aparência visceralmente menos próxima. Citando Phillips, "a guerra interior é sempre pior do que a guerra exterior. [...] A guerra interior corresponde à verdade acerca do eu; a guerra exterior limita-se a ser história" (Phillips, 2000a: 52).

Passando, por via destas observações, aos temas mais directamente debatidos neste colóquio, assinale-se aqui a faceta de uma guerra, a troiana, que, de um certo ponto de vista, e como a bela Helena belamente o entendeu, também foi, ou foi primordialmente, colonial e motivada por interesses mercantis:

ETRA - Cada homem em casa, com a sua família e com os seus negócios. 
HELENA - Que, por causa de Tróia não lhes corriam bem. Cada chefe, ao abrigo da sua cidadela, procurando um pretexto para lhe mover guerra. Porque lá isso, diga-se a verdade, não somos gente bárbara. Nunca fazemos uma guerra sem pretextos. (56)

ETRA - A que remorsos julgas ter direito? Destruiste meio mundo, é certo, mas que culpa terás tu [...] de que os reis da Grécia decidissem que era uma boa altura e um bom pretexto para destruirem Tróia, como queriam? (76)

Será então, que, de certo modo, (ou pelo menos no entendimento do colonizador e, certamente, do colonizador português) a Guerra Colonial foi também, ou porventura exclusivamente, uma guerra civil, a guerra dentro do eu (visto que, no caso, e salazaristicamente falando, as colónias faziam supostamente parte integral do eu pátrio, parte da família?) $\mathrm{Na}$ secção final desta leitura, será sugerido que em $O$ rancor o inimigo (Páris, os Troianos) que, embora perigoso, cobiçoso, usurpador e ocasionalmente mortífero, tinha tido, pressupostamente, pelo menos o mérito de ser identificavelmente Outro, estrangeiro, diferente, reconhecível, gerível e controlável como tal vem a ser afinal, por acção de Helena, clandestinamente contrabandeado para o próprio âmago da família grega, que descobre, afinal de contas, nunca ter conseguido verdadeiramente excomungá-lo.

Para Phillips, a guerra oferece os parâmetros (assim como a psicanálise oferece a disciplina paradigmática), necessários à enunciação da pergunta "o que é um inimigo?" (Phillips, 2000a: 44). Phillips deixa-nos com uma pergunta retórica: será que, psicanaliticamente, a definição de desenvolvimento psicológico e erótico se resume afinal ao processo de identificação do inimigo e de estabelecimento de um relacionamento amistoso com ele(a)? (Phillips, 2000a: 39). Se a identificação de um inimigo e a promoção de boas relações com ele(a) definem o processo de desenvolvimento psíquico que nos transpõe da infância para a maturidade, o que esse processo de mudança implica, por definição, é uma alteração fundamental, uma vez que nada jamais voltará a ser o que era. You can't go home again. E quando as coisas não voltam a ser o que eram, o imperativo que se levanta é o da necessidade de novas representações para um novo status quo.

Nesta última secção, será abordada a questão de uma carnavalização pseudo-bakhtiniana, segundo a qual, quando as máscaras são depostas (ou, como especificamente aqui, arrancadas), o espectáculo que se nos depara é o de um mundo às avessas, em que, aconteça o que acontecer, nada nem ninguém jamais voltará a ser o mesmo.

A revelação de que Helena trazia a cabeça rapada é uma encenação semiótica de ressonância dupla e confusa na sua categorização: ao arvorar simul- 
taneamente a auréola das viúvas fiéis e a ignomínia das adúlteras ostracizadas ("Como as viúvas! Como as descasadas!" [52]), a figura de Helena desmorona todo o entendimento colectivo do status quo pós-troiano, que promovera a versão de uma Helena involuntariamente raptada, cativa, fiel ao marido, grata pelo eventual regresso ao lar conjugal, em suma, sempre e visceralmente grega. A hipótese perturbante que, para os Gregos fica sempre inquietantemente críptica e enunciada apenas por associação com o caso de Etra - que, fica subentendido, se assemelha ao de Helena - é a possibilidade de ter sido esta, tal como porventura aquela, voluntariamente foragida e não refém:

HELENA - Diz, Etra, [...] parece que foste tu quem sugeriu [que] ficasse[s] minha escrava, era vingança que bastava e assim não mais se falaria do assunto.

ETRA - Eu é que sugeri?

HELENA - Ou eu, não sei. Não te queria deixar.

ETRA - Não nos deixámos. (51)

E se Helena não foi raptada mas, tal como Etra, partiu de seu livre arbítrio, sendo que o seu estatuto de refém/emigrante voluntária fica sempre ambíguo, ambíguas ficam também a vitória grega sobre uma Tróia estranha, agreste, "já Ásia" (23), e todas as certezas advindas dessa vitória. Como representar, então, este admirável mundo novo, com as suas verdades ocultas e tardiamente, relutantemente, reconhecidas como imponderáveis? Adam Phillips, relendo André Green, relaciona o problema da paixão com o da sua representação. É através da representação que evitamos a deslembrança de sensações vividas, e o desespero, porque "o desespero é uma forma de se estar desatento". Se "o ser passional é a melhor parte do que somos", o acto de sentir é também um acto de representação, o significante da carne e a mise en scène da paixão (Phillips, 2000b: 300). Uma vida passional, por definição, apenas se torna possível se essa paixão alcançar enunciação, perante nós próprios e perante o seu objecto (e ainda perante a colectividade que é o palco e a assistência dessa paixão). Para Green e para Phillips, não existe a possibilidade de uma paixão privada, ou de uma linguagem passional privada: a paixão requer movimento, intercâmbio e comunicação (Phillips, 2000: 300-309). E ainda, diríamos agora, representação: é, de facto, no espírito dos homens, e acima de tudo das mulheres (é ver o exemplo da Lisístrata de Aristófanes), que se erguem as defesas da paz, pela via do amor.

Homero, n'A Odisseia, dera-nos a versão balsâmica dos acontecimentos míticos (balsâmica para tudo aquilo que em nós é grego e não troiano, euro-clássico e não asiático, convencional e não desabrido, e, acima de tudo, 
receoso e não seduzido pelo poder disruptor da paixão). A Helena homérica devolvida a Esparta, perfeita anfitriã e fada do lar restaurada, acolhe Telémaco, cujo pai continua desaparecido, afinal de contas e indiscutivelmente por culpa dela, e, com soberbo auto-domínio, evoca os acontecimentos que levaram a que "vós, Gregos, declarásseis guerra contra Tróia por amor de mim, desavergonhada criatura que eu era!” (Homero, 1985: 68)

"Vós, Gregos", porém, estabelece não o remorso tardio mas antes uma recalcitrante e teimosa linha divisória entre ela e eles, o Eu e o Outro, deixando entrever de que lado da rixa a bela Helena afinal de contas, desde sempre e para sempre se situa. Também em Hélia Correia, quando a cabeleira é arrancada, a representação até então privada (secreta) da paixão e do luto eterno infiltra à força o discurso da família, da polis e da colectividade grega, e o efeito é o de uma declaração de guerra, apenas com um formato ligeiramente diferente: um formato feminino e, por essa razão, não militarista, mas, à outrance, discursivo/político/diplomático. A declaração feita por aquela cabeça desnudada - cujo efeito é roubar aos Gregos o seu mais precioso troféu (a mulher mais bela do mundo, agora reduzida a uma "mulherzinha" feia e careca) - é o desmentido da versão pacata de um regresso grego e espartano, de guerreiros triunfantes e de esposas comprovadamente amantíssimas, bem como a afirmação de que afinal a esposa supostamente submissa de Menelau é, afinal de contas, a viúva inconsolável de Páris, aquele menino da sua mãe/amante, que "no plaino abandonado jaz morto e arrefece" (Pessoa, 1981: 31-32).

Se, conforme proclama Desmond Tutu na epígrafe que escolhi para este texto, um inimigo é um amigo (ou, digo eu agora, um amante) à espera de se tornar realidade, num texto tão ressonante dos enredos épicos e trágicos como o de Hélia Correia, não é o filho edipiano que vem a transformar-se em amante/marido da mãe, mas, contrariamente, é o inimigo, Páris, quem renasce, por via da intensidade e persistência memorializante da amante, Helena, enquanto ser a quem ela pseudo-maternalmente gerou, existência e ressurreição por via da acção da memória renitente, contrabandeada para o seio de uma família tão arisca, tão em guerra (civil) como as famílias gregas míticas sempre foram. N'A Odisseia, Helena aparece enquanto esposa aparentemente impávida, restaurada à respeitabilidade conjugal, e aparentemente serena frente ao cataclismo que aniquilou um amante, um povo e uma civilização. Mas no final de $O$ rancor, o seu trunfo e o seu triunfo residem na constatação de possuir ela afinal de contas um coração helenicamente isento, é certo, porém fidelissimamente troiano, através do qual sonega à Grécia, supostamente triunfante, o amor que permaneceu na cidade sitiada. E Ílion rendida retém, a pesar disso, a vitória que lhe concedeu a mulher 
mais bela do mundo, por via do sucesso alcançado na transfiguração do inimigo troiano (Páris), em eterno amante eternamente bem-amado, em vida e para além da morte, mas em ambos os casos sempre de algum modo presente. Até ao fim do mundo.

No imaginário lusófono, caracterizado por Fernando Pessoa em Mensagem, por "olhos gregos, lembrando" (Pessoa, 1979: 21), o amor é quase sempre de perdição. E o rancor, a este tão frequentemente ligado, também. A definição de "rancor" é o ódio que não esquece, e que, aqui, perpetua os meandros indestrinçavelmente emaranhados de Eros e de Tanatos, do amor e do ódio, assegurando não ser nada jamais o que parece. Na Grécia pressupostamente restaurada, as esposas são infiéis e/ou assassinas; os filhos amam as mães assassinas e vingam os pais sem conviç̧ão ("E quando o braço com o punhal desceu [...], e o sangue o atingiu em pleno rosto, [Orestes] viu os olhos [da mãe] e desejou que tudo se tivesse passado exactamente de maneira contrária. Ele de bom grado mataria a irmã, e o pai, e a tia, Helena, a grande prostituta." [69, sublinhado meu]); os irmãos choram-se uns aos outros com lágrimas de crocodilo ("HELENA - É um rei com juízo, Menelau. Morto o irmão, é nele que habita agora toda a grandeza do triunfador. [...] Sempre que fala nisso, Menelau não consegue evitar um pequeno, pequenino sorriso." [60-61]); os vencedores decaem ("HELENA - Pobre Agamemnon. Vir morrer numa banheira, às mãos de uma mulher, entre perfumes, ele, chefe supremo dos exércitos.” [61]); e os vencidos (Páris) são inquietantemente restaurados. Restaurados, porém, não por uma força militar já agora comprovadamente ineficaz, mas, no caso do belo amante "de olhos langorosos" (76) da bela Helena, pelo poder da memória, da representação, e daquele feminino amor ardente que, com erros de todos e má fortuna, em sua imortalização se conjuraram.

\section{Referências Bibliográficas}

Cooper, Helen et al. (1989), "Arms and the Woman: The Con(tra)ception of the War Text," in H. Cooper et al. (orgs.), Arms and the Woman: War, Gender and Literary Representation. Chapel Hill/London: The University of North Carolina Press, 9-24. Correia, Hélia (2000), O rancor. Exercício sobre Helena. Lisboa: Relógio d'Água.

Chodorow, Nancy (1979), The Reproduction of Mothering: Psychoanalysis and the Sociology of Gender. Berkeley / Los Angeles / London: The University of California Press.

Ésquilo (1985), The Oresteian Trilogy. Trad. Philip Vellacott. Harmondsworth: Penguin. Eurípides (1978), Iphigenia in Aulis. Trad. W. S. Merwin e George E. Dimock, Jr. New York: Oxford UP. 
Eurípides (1989), Medea and Other Plays. Trad. Philip Vellacott. Harmondsworth: Penguin.

Freeman, Barbara (1989), "Epitaphs and Epigraphs: 'The End(s) of Man'”, in H. Cooper et al. (orgs.), Arms and the Woman: War, Gender and Literary Representation. Chapel Hill/London: The University of North Carolina Press, 303-322.

Freud, Sigmund (1950), Totem and Taboo. Trad. James Strachey. Standard Edition, vol. 13. London: Hogarth Press [1912-13].

Freud, Sigmund (1957), “Thoughts for the Times on War and Death”. Trad. James Strachey. Standard Edition, vol. 14. London: Hogarth Press, 275 ss. [1915].

Freud, Sigmund (1961), Beyond the Pleasure Principle. Trad. James Strachey. Standard Edition, vol. 18. London: Hogarth Press [1920].

Freud, Sigmund (1962), Three Essays on the Theory of Sexuality. Trad. James Strachey. Standard Edition, vol. 7. London: Hogarth Press [1905].

Grant, Michael; Hazel, John (1993), Who's Who in Classical Mythology. London: Dent. Helms, Lorraine (1989), “'Still Wars and Lechery:' Shakespeare and the Last Trojan Woman”, in H. Cooper et al. (orgs.), Arms and the Woman: War, Gender and Literary Representation. Chapel Hill/London: The University of North Carolina Press, $25-42$.

Homero (1984), The Odyssey. Harmondsworth: Penguin.

Homey, Karen (1993), Feminine Psychology. New York/London: Norton.

Pessoa, Fernando (1979), Mensagem. Lisboa: Ática.

Pessoa, Fernando (1981), Poesia. Rio de Janeiro: Livraria Agir Editora.

Phillips, Adam (2000a), "Bombs Away", in A. Phillips, Promises, Promises. Essays on literature and psychoanalysis. London: Faber and Faber, 35-58.

Phillips, Adam (2000b), "The Pragmatics of Passion”, in A. Phillips, Promises, Promises. Essays on literature and psychoanalysis. London: Faber and Faber, 296-309.

Segal, Naomi (1990), "Patrilinear and Matrilinear", in Halen Wilcox et al. (orgs.), The Body and the Text: Hélène Cixous, Reading and Teaching. New York/London: Harvester Wheatsheaf, 131-46.

UNESCO (1945), Acto Constitutivo (http://www.unesco. web.ptlactoconstitutivo.htm). 